\title{
WHIPLASH INJURIES
}

\author{
A TRIAL OF EARLY MANAGEMENT
}

BRUCE H. PENNIE, LINDSAY J. AGAMBAR

From Arrowe Park Hospital, Wirral, Merseyside

\begin{abstract}
We have conducted a prospective trial of the management of 135 adult patients who had sustained softtissue injuries of the neck in vehicle accidents. Early traction and physiotherapy was compared with rest in a collar and unsupervised mobilisation. No benefit from the active treatment could be identified; moulded collars in slight flexion gave the best pain relief and are recommended.
\end{abstract}

Soft-tissue cervical spine injuries to occupants of vehicles - whiplash injuries - are common, and symptoms often persist for several months. Despite this, there is no consensus on management; where the injury is assumed to be a sprain of the soft tissues of the neck, a collar is often recommended. The reported duration for which it was worn has varied from two weeks upwards (Gay and Abbott 1953; Macnab 1964; Hohl 1975; Marshall 1976), but many patients were reported to have worn collars for prolonged periods (Balla 1980; Norris and Watt 1983).

The only prospective trial we could find followed 61 patients for eight weeks (Mealy, Brennan and Fenelon 1986), and showed that a programme of early Maitland mobilisation appeared to be superior to the use of a collar for two weeks followed by graduated exercises. Unfortunately, the active treatment was not described in enough detail for it to be faithfully reproduced. Active treatment appears to be becoming more popular; this usually involves a physiotherapy department, and imposes a heavy work-load, while the patients also incur expense and inconvenience. We felt that the benefits of active treatment had not been adequately assessed and therefore planned to evaluate our version of this method.

\section{PATIENTS AND METHODS}

Over a 20 -week period in 1986, all adult patients who had sustained soft-tissue injuries of the neck while riding in vehicles involved in road traffic accidents, were referred from the two accident units of the Wirral Health

B. H. Pennie, MCh (Orth), FRCS E, Registrar in Orthopaedic Surgery Broadgreen Hospital, Thomas Lane, Liverpool L14 3LB, England.

L. J. Agambar, MCSP, SRP, Superintendent Physiotherapist Haywards Heath Hospital, Haywards Heath, West Sussex RH16 4BE, England.

Correspondence should be sent to Mr B. H. Pennie at 6, Belle Vue Road, Liverpool, L25 2QD, England

(C) 1990 British Editorial Society of Bone and Joint Surgery $0301-620 X / 90 / 2026 \$ 2.00$

J Bone Joint Surg [ Br] 1990; 72-B: 277-9.
Authority (population 357 500) to a research clinic held three times weekly. Standard soft collars were provided initially, and at the research clinic, random allocation was made on the basis of the casualty number to either standard treatment or treatment by physiotherapy. The study had the approval of the District Medical Ethics Committee, and it was intended to follow about 150 patients.

Table I. Patients' assessment of results related to method of treatment, number and percentage

\begin{tabular}{lcccccccccc}
\hline & \multicolumn{1}{c}{ At six to eight weeks } \\
\cline { 2 - 8 } & Cured & \multicolumn{3}{c}{ Improved } & Same & \multicolumn{2}{c}{ Worse } \\
\hline $\begin{array}{l}\text { Collar } \\
\text { (13 excluded) }\end{array}$ & 35 & 57 & 16 & 26 & 5 & 8 & 5 & 8 \\
$\begin{array}{l}\text { Traction } \\
\text { (13 excluded) }\end{array}$ & 22 & 46 & 18 & 38 & 6 & 13 & 2 & 4 \\
All & 57 & 52 & 34 & 31 & 11 & 10 & 7 & 6 \\
$\begin{array}{l}\text { Collar } \\
\text { (4 excluded) }\end{array}$ & 64 & 91 & 5 & 7 & 1 & 1 & 0 & \\
$\begin{array}{l}\text { Traction } \\
\text { (3 excluded) }\end{array}$ & 47 & 81 & 9 & 16 & 2 & 3 & 0 \\
All & 111 & 87 & 14 & 11 & 3 & 2 & 0 \\
\hline
\end{tabular}

Standard treatment was two weeks rest in either a soft collar or a moulded one of thermoplastic polyethylene foam. Patients were then reviewed and taught a programme of active exercises. At six to eight weeks, patients who had failed to improve, or who had deteriorated, were then referred for physiotherapy.

The active treatment was by traction and exercises. Patients attended twice a week and had intermittent halter traction for 10 minutes: $12 \mathrm{lb}(5.4 \mathrm{~kg})$ was applied 
for 30 seconds with 30 -second rest periods. The traction was applied in extension, neutral position or flexion for upper, mid or lower neck pain respectively. Patients received advice on neck care and sleeping posture and, between attendances, were advised to perform simple neck and shoulder exercises.

Table II. Mean and range of total movement in degrees (see text) at presentation and at review

\begin{tabular}{llll}
\hline & Presentation & At six to eight weeks & At five months \\
\hline Collar & $288(85$ to 455$)$ & $361(240$ to 445$)$ & $377(190$ to 460$)$ \\
Traction & $276(85$ to 425$)$ & $366(140$ to 470$)$ & $366(140$ to 470$)$ \\
\hline
\end{tabular}

Follow-up was continued until the patients felt they had recovered, or up to a maximum of five months. Those who failed to attend the review clinic were visited at home about five months after their injury. At review, total neck mobility was measured in degrees, using a goniometer, as the sum of flexion, extension, left and right lateral flexion and left and right rotation. Pain was assessed at four sites (neck, arm, back and head) using visual linear analogue pain scales $(0=$ no pain, $100=$ worst possible pain).

Table III. A verage percentage reductions in pain scores at six to eight weeks (A) and five months (B), with the numbers of patients assessed

\begin{tabular}{|c|c|c|c|c|c|c|c|c|}
\hline & \multicolumn{2}{|c|}{ Neck } & \multicolumn{2}{|c|}{ Back } & \multicolumn{2}{|c|}{ Arm } & \multicolumn{2}{|c|}{ Head } \\
\hline & $\begin{array}{l}\text { 2nd } \\
\text { A }\end{array}$ & $\begin{array}{l}\text { Final } \\
\text { B }\end{array}$ & $\begin{array}{l}\text { 2nd } \\
\text { A }\end{array}$ & $\begin{array}{l}\text { Final } \\
\text { B }\end{array}$ & $\begin{array}{l}\text { 2nd } \\
\text { A }\end{array}$ & $\begin{array}{l}\text { Final } \\
\text { B }\end{array}$ & $\begin{array}{l}\text { 2nd } \\
\text { A }\end{array}$ & $\begin{array}{l}\text { Final } \\
\text { B }\end{array}$ \\
\hline \multicolumn{9}{|l|}{ Collar } \\
\hline per cent & 64 & 88 & 69 & 98 & 95 & 99 & 56 & 77 \\
\hline number & 61 & 70 & 19 & 20 & 12 & 13 & 30 & 32 \\
\hline \multicolumn{9}{|l|}{ Traction } \\
\hline per cent & 68 & 90 & 64 & 77 & 78 & 68 & 41 & 76 \\
\hline number & 48 & 58 & 14 & 17 & 6 & 8 & 18 & 23 \\
\hline \multicolumn{9}{|l|}{ All } \\
\hline per cent & 66 & 89 & 67 & 88 & 89 & 87 & 50 & 76 \\
\hline number & 109 & 128 & 33 & 37 & 18 & 21 & 48 & 55 \\
\hline
\end{tabular}

\section{RESULTS}

Of the 152 patients diagnosed initially, 17 were excluded: 12 because of failure to attend the clinic during the first week, two who were temporary visitors to the area, one who had recovered by first attendance, one who required bed rest for back injury and one who declined entry to the trial.

Of the 135 patients entering the study, 74 had collar treatment and 61 had traction. The collar group included
36 men and 38 women and the traction group 22 men and 39 women, and there was also an inequality between social classes 1 to $3 \mathrm{n}$ and $3 \mathrm{~m}$ to 5 (Office of Population Censuses and Surveys 1980) with a higher proportion of classes 1 to $3 \mathrm{n}$ in the traction group (collar 30:33, traction $33: 18)$. In all other respects the groups were comparable. Of the collar group, 16 received moulded collars before the technician who made them fell ill; subsequently standard soft collars were issued. Apart from the fact that the moulded collars were preferred by 15 of the 16 who tried both, there were no significant differences between the two groups and their results have been combined.

Results are presented at the six to eight weeks and the final (five months) review. Three patients were excluded from both reviews : two randomised to the collar group sought and received active treatment elsewhere, and one who sustained a second injury at three weeks and had not recovered at five months. Of the 23 patients who missed the six to eight week review, 20 failed to keep their appointments and three had sustained a second injury. These three subsequently recovered and are included in the five-month review. Four other patients could not be traced, leaving 128 available for the full review.

\begin{tabular}{|c|c|c|c|}
\hline \multirow{2}{*}{$\begin{array}{l}\text { Treatment } \\
\text { Group }\end{array}$} & \multirow[b]{2}{*}{ All } & \multicolumn{2}{|c|}{ Social class } \\
\hline & & $1,2,3 n$ & $3 m, 4,5$ \\
\hline $\begin{array}{l}\text { Collar } \\
\text { days } \\
\text { number }\end{array}$ & $\begin{array}{l}26(17) \\
57\end{array}$ & $\begin{array}{l}19(12) \\
26\end{array}$ & $\begin{array}{l}32(20) \\
31\end{array}$ \\
\hline $\begin{array}{l}\text { Traction } \\
\text { days } \\
\text { number }\end{array}$ & $\begin{array}{l}31(11) \\
48\end{array}$ & $\begin{array}{l}19(5) \\
32\end{array}$ & $\begin{array}{l}54(54) \\
16\end{array}$ \\
\hline $\begin{array}{l}\text { All } \\
\text { days } \\
\text { number }\end{array}$ & $\begin{array}{l}28(14) \\
105\end{array}$ & $\begin{array}{l}19(7) \\
58\end{array}$ & $\begin{array}{l}40(23) \\
47\end{array}$ \\
\hline
\end{tabular}

Table I shows the patients' own assessments, and Table II the total ranges of movement at second and final reviews. We found no significant differences between the groups; this held true when the unequal distributions of sex and social class were allowed for. There was no greater tendency to improvement in neck pain score in the traction group at eight weeks (mean improved from 45 to 15 ) than in the collar group (mean improved from 44 to 16). We felt that the percentage improvement in pain score for each individual patient might be a better measure of improvement. This was calculated for each of the four sites for pain; these mean values also showed no benefit to the traction group (Table III). 
Time off work did not depend on treatment (Table IV), but did vary with social class, being shorter in classes 1 to $3 \mathrm{n}$ (Mann-Whitney U-test, $\mathrm{z}=3.22, \mathrm{p}<0.001$ ).

\section{DISCUSSION}

We compared one specific method of active treatment with a standard, cheaper alternative and found no benefit at either the short-term (six to eight weeks) or mediumterm (five-months) reviews. Our findings do not, of course, necessarily apply to other active treatments, such as that used by Mealy et al (1986) in their smaller series. We feel that our study is of sufficient size for it to be unlikely that we have missed a clinically important effect. We cannot recommend the use of the active treatment we have described, and feel that any alternative should be rigorously evaluated because of the expense and resources involved.

It was unfortunate that moulded collars were not available for the whole series, but the patients' preference for collars in neutral or slight flexion was quite striking.
Some standard collars tend to splint the neck in slight extension, placing tension on damaged anterior structures. Moulded collars seem to give more pain relief, and are therefore recommended.

We thank Mr J. Marrow for allowing us to study patients under his care.

No benefits in any form have been received or will be received from a commercial party related directly or indirectly to the subject of this article.

\section{REFERENCES}

Balla JI. The late whiplash syndrome. Aust NZ Surg 1980; $50: 610-4$.

Gay JR, Abbott KH. Common whiplash injuries of the neck. JAMA 1953; 152:1698-1704.

Hohl M. Soft tissue injuries of the neck. Clin Orthop 1975; 109:42-9.

Macnab I. Acceleration injuries of the cervical spine. An instructional course lecture AAOS J Bone Joint Surg [Am] 1964; 46-A:1797-9.

Mealy K, Brennan H, Fenelon GCC. Early mobilisation of acute whiplash injuries. Br Med J 1986; $292: 656-7$.

Marshall LL. The "whiplash" injury. Med J Aust 1976; 2:26-7.

Norris SH, Watt I. The prognosis of neck injuries resulting from rearend vehicle collisions. J Bone Joint Surg [Br] 1983; 65-B:608-11.

Office of Population Censuses and Surveys. Classification of occupations 1980. London: HMSO, 1980 